\title{
PERTANGGUNGJAWABAN PENGURUS KOPERASI APABILA TERJADI KREDIT MACET DARI ANGGOTA KOPERASI DALAM LINKAGE PROGRAM POLA CHANNELING DITINJAU DARI TEORI PERTANGGUNGJAWABAN BADAN HUKUM KOPERASI
}

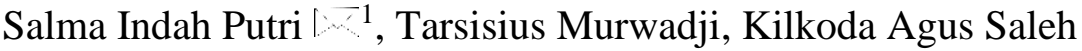

Program Studi Sarjana Ilmu Hukum, Fakultas Hukum Universitas Padjadjaran

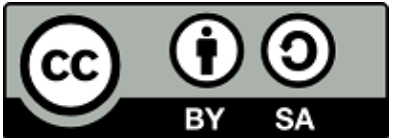

DOI: http://dx.doi.org/10.33603/hermeneutika.v3i2

Diterima: 4 Desember 2019; Direvisi: 20 Januari 2020; Dipublikasikan: Februari 2020

Abstrak: Usaha Mikro, Kecil, dan Menengah (UMKM) sebagai badan usaha yang tidak berbadan hukum memiliki peran besar dalam pembangunan ekonomi nasional. Pemerintah dengan tujuan untuk memudahkan UMKM mengakses pendanaan dari perbankan membuat pengaturan mengenai linkage program. Linkage program memiliki tiga pola yaitu: channeling, executing, dan joint financing. Dalam linkage program pola channeling kedudukan Koperasi hanya sebagai penghubung antara Bank Umum dengan Anggotanya dan tidak mempunyai kewenangan untuk memutus pemberian kredit kepada Anggotanya. Akan tetapi, apabila terjadi kredit macet dari Anggota Koperasi menimbulkan permasalahan perihal pertanggungjawaban Pengurus Koperasi atas kredit macet tersebut.
\end{abstract}

Kata kunci: Linkage Program, Koperasi, Channeling, Pertanggungjawaban

\footnotetext{
${ }^{1}$ Salma Indah Putri I

Email: alma.indahh@yahoo.com
} 


\section{PENDAHULUAN}

Indonesia sebagai negara berkembang terus melakukan pembaruan dalam penyelenggaraan negara seiring dengan perkembangan zaman untuk menjadi negara yang dapat mensejahterakan dan memakmurkan seluruh rakyatnya. Pasal 1 ayat (3) UUD RI 1945 secara jelas telah menyatakan bahwa Indonesia merupakan Negara hukum. Indonesia sebagai negara hukum yang bercirikan negara hukum kesejahteraan (welfare state) memegang peran penting dalam melindungi dan menjamin kesejahteraan rakyatnya melalui kebijakan yang mengakomodasi kepentingan rakyat demi tercapainya kesejahteraan rakyat yang dicita-citakan. ${ }^{2}$

Dalam usaha untuk mencapai tujuan yang dicita-citakan tersebut, Indonesia melaksanakan berbagai upaya salah satunya dengan menyelenggarakan pembangunan nasional. Pembangunan nasional dapat dilaksanakan dalam beberapa bidang, salah satunya adalah pembangunan di bidang ekonomi. Sistem perekonomian setiap negara berbeda-beda di mana Indonesia sendiri merupakan negara yang menganut sistem ekonomi "demokrasi". Sistem demokrasi ekonomi yang dianut Indonesia berlandaskan dari Pasal 33 Ayat (1) dan (4) Undang-Undang Dasar Tahun 1945.

Dewasa ini perkembangan kegiatan perekonomian di Indonesia sangat dipengaruhi oleh bermacam-macam kegiatan yang dilakukan oleh badan usaha. Badan usaha memiliki kesatuan yuridis dan ekonomis dari faktor-faktor produksi yang mempunyai tujuan untuk mencari laba atau untuk menyediakan pelayanan bagi masyarakat. Pada penggolongannya, terdapat badan usaha yang berbadan hukum yang meliputi Perseroan Terbatas (PT), Koperasi, dan Yayasan, dan terdapat badan usaha yang tidak berbadan hukum yang meliputi Persekutuan Perdata (Matschaap), Firma, dan Perseroan Komanditer (CV).

${ }^{2}$ Fathoni, "Masyarakat Ekonomi Asean (MEA) 2015 dan Tantangan Negara Kesejahteraan", Jurnal Penelitian Hukum Supremasi Hukum, Vol. 24, No. 2, 2015, hlm. 125.
Konsekuensi dari suatu badan usaha yang berbadan hukum adalah badan hukum dapat melaksanakan aktivitas dan mengikatkan diri layaknya setiap pribadi manusia, memiliki kekayaan sendiri atau hutang, maupun bertindak sebagai pemangku hak dan kewajiban. Hal tersebut tidak lepas dari esensi badan hukum yang merupakan salah satu subjek hukum selain manusia.

Koperasi adalah badan usaha (Pasal 1 Undang-Undang Nomor 25 Tahun 1992 tentang Perkoperasian) yang berbadan hukum. Dalam kaitannya sebagai sebuah badan usaha, Koperasi tetap tunduk terhadap kaidah-kaidah perusahaan dan prinsipprinsip ekonomi yang berlaku dengan tetap berlandaskan asas kekeluargaan. Karena itu Koperasi harus dapat menghasilkan keuntungan dalam mengembangkan organisasi dan usahanya. Tujuan Koperasi termuat dalam Undang-Undang Nomor 25 Tahun 1992 yaitu Koperasi bertujuan untuk memajukan kesejahteraan anggota pada khususnya dan masyarakat pada umumnya serta ikut membangun tatanan perekonomian nasional dalam rangka mewujudkan masyarakat yang maju, adil, dan makmur berdasarkan Pancasila dan UUD 1945. Sedangkan Tiktik S. Partomo mengemukakan bahwa tujuan perusahaan Koperasi antara lain: ${ }^{3}$

a. mempertahankan, jika mungkin meningkatkan bagian pasar dari satu (beberapa) barang dan jasa, dan menekan serendah-rendahnya biaya produksi, yang harus lebih rendah atau sekurang-kurangnya sama dengan biaya produksi para pesaingnya;

b. melindungi potensi ekonomisnya, menjaga/mengamankan likuditasnya, dan menciptakan inovasi.

Pada era yang sudah berkembang pada saat ini, dapat dijumpai beberapa Koperasi yang masih baru dan belum

\footnotetext{
3 Tiktik Sartika Partomo, Ekonomi Koperasi, Bogor:
} Ghalia Indonesia, 2009, hlm. 35. 
berpengalaman dimana terdapat permasalahan internal di dalamnya. Faktor internal tersebut salah satunya adalah modal usaha dan lapangan usaha yang terbatas, ${ }^{4}$ sehingga sebagian Koperasi hanya mengelola satu jenis usaha, dan sifatnya temporer, dan monoton dikarenakan iuran anggotanya tidak cukup untuk membiayai keseluruhan operasional Koperasi. Koperasi tersebut akibatnya juga belum dapat memberikan pinjaman kepada anggotanya.

Koperasi dengan kondisi tersebut membutuhkan bantuan eksternal dari lembaga keuangan antara lain Bank dan lembaga pembiayaan. Untuk mendukung faktor eksternal dan internal pada Koperasi tersebut dapat dilakukan dengan linkage program perbankan. Pengaturan mengenai Linkage Program termuat dalam Peraturan Menteri Negara Koperasi dan Usaha Kecil dan Menengah Republik Indonesia No: 03/Per/M.KUKM/III/2009 tentang Pedoman Umum Linkage program antara Bank Umum dengan Koperasi.

Linkage program merupakan suatu kerjasama yang pada dasarnya saling menguntungkan antara Bank dengan Koperasi dengan memberikan peluang bagi koperasi agar dapat bekerja sama dengan bank umum dan bank syariah dalam pengurusan dan pencarian kredit. Dengan Linkage Program tersebut Koperasi dapat belajar untuk mendapatkan dan mengelola dana, dengan begitu saling menguntungkan pihak-pihak terkait dikarenakan hal ini dapat memberikan keuntungan kepada Bank, menjaga citra Koperasi, dan dapat mengembangkan kegiatan UMKM yang sebelumnya sulit untuk mendapatkan Kredit Perbankan karena belum mempunyai badan hukum.

Dalam linkage program terdapat tiga pola, yaitu Pola Channeling, Executing, dan Joint Capital. Penelitian ini mengkhususkan

4 H.A.M. Nurdin Halid, Membangun Simbol, Meruntuhkan Mitos Marginal Koperasi, Jakarta: Forum Studi dan Solidaritas Koperasi Indonesia, 1999, hlm. 30.

${ }^{5}$ Zulfi Diane Zaini, Implementasi Pendekatan Yuridis Normatif dan Pendekatan Normatif Sosiologis pada pola yang pertama, yaitu Pola Channeling dimana kedudukan Koperasi sebagai penghubung antara Bank dengan anggota Koperasi. Penghubung di sini dalam arti luas, yaitu membantu Bank dalam semua kegiatannya, mulai dari pemilihan calon nasabah, menseleksi karakteristik nasabah yang baik, membantu menyusun perjanjian dan penggunaan keuangan.

Dengan Pola Channeling ini terdapat dua manfaat bagi Koperasi, yaitu belajar mengenai sistem keuangan, dan memperoleh penghasilan dari jasa sebagai penghubung antara Bank dengan Anggota Koperasi lainnya tersebut.

Permasalahan yang terjadi adalah di mana masyarakat belum mengenal Linkage Program Pola Channeling sehingga jika suatu saat terjadi kredit macet Koperasi seolah-olah harus bertanggungjawab, padahal kedudukan hukumnya hanyalah sebagai penghubung.

\section{II.METODE PENELITIAN}

Metode peneltian yang digunakan adalah pendekatan yuridis normatif. Metode pendekatan ini dilakukan agar dapat melakukan temuan-temuan, pergantian ataupun perubahan dari berbagai teori dalam disiplin ilmu hukum melalui proses ilmiah. ${ }^{5}$

Untuk meneliti mengenai spesifikasi penelitian dapat digunakan metode deskriptif analitis dengan menjelaskan, menggambarkan, serta mengkorelasikan peraturan dan teori hukum dengan permasalahan yang terjadi. ${ }^{6}$ Maka itu, spesifikasi penelitian ini adalah meninjau pertanggungjawaban Pengurus Koperasi dalam hal terjadi kredit macet dari anggotanya dalam linkage program pola channeling.

\section{HASIL DAN PEMBAHASAN}

dalam Penelitian Ilmu Hukum. Pranata Hukum Vo. 6 No. 2, 2011, hlm. 126.

${ }^{6}$ Sugiyono, Metode Penelitian Bisnis (Pendekatan

Kuantitatif, Kualitatif, dan R\&D), Bandung:

Alfabeta, 2009, hlm. 29. 


\section{a. Pertanggungjawaban sebagai Badan Hukum}

Koperasi

Menurut Wirjono Prodjodikoro ada perkumpulan yang berbadan hukum dan banyak yang tidak berstatus badan hukum. ${ }^{7}$ Badan hukum adalah suatu badan atau perkumpulan yang dapat memiliki hak-hak dan melakukan perbuatan seperti seorang manusia, serta memiliki kekayaan sendiri, dapat digugat dan mengggugat di depan hakim. ${ }^{8}$

Karakteristik badan hukum adalah memiliki kekayaan sendiri, anggaran dasar disahkan oleh pemerintah, dan diwakili oleh pengurus. ${ }^{9}$ Badan hukum mampu melakukan hubungan-hubungan hukum atau mengadakan perjanjian-perjanjian baik tertulis atau tidak tertulis dengan pihak ketiga. ${ }^{10}$ Badan hukum dapat mempunyai hak-hak dan kewajiban-kewajiban hukum dan dapat mengadakan hubungan hukum, ${ }^{11}$ sehingga pada dasarnya badan hukum dapat bertanggung jawab dalam hal perbuatan melawan hukum, sama kedudukannya dengan manusia sebagai subjek hukum. Perbuatan hukum dari badan hukum memiliki mekanisme pelaksanaan tindakan melalui perantara pengurus.

Sebagai subyek hukum mandiri, Koperasi sebagai badan hukum dimungkinkan melakukan perbuatan melawan hukum, sehingga berkaitannya dengan teori pertanggungjawaban bahwa badan hukum dapat melakukan tanggung jawab atas setiap perbuatan hukum yang dilakukan oleh badan hukum tersebut. Terdapat beberapa teori yang dikenal dalam pertanggungjawaban badan hukum. Munir Fuady menyatakan bahwa ilmu hukum mengenal tiga kategori dari perbuatan melawan hukum sebagai berikut: ${ }^{2}$

\footnotetext{
${ }^{7}$ Wirjono Prodjodikoro, Hukum Perkumpulan Perseroan Dan Koperasi Di Indonesia, Bandung: Penerbit Dian Rakyat, 1985, hlm. 10.

${ }^{8}$ Chidir Ali, Badan Hukum, Bandung: Penerbit Alumni, 1999, hlm. 14.

${ }^{9}$ Abdulkadir Muhammad, Hukum Perusahaan Indonesia, Bandung : PT Citra Aditya Bakti, 2010, hlm. 101.

${ }^{10}$ Chidir Ali, Op.Cit., hlm. 168.
}

1. Perbuatan melawan hukum karena kesengajaan;

2. Perbuatan melawan hukum tanpa kesalahan (tanpa unsur kesengajaan ataupun kelalaian); dan

3. Perbuatan melawan hukum karena kelalaian.

Tiga kategori perbuatan melawan hukum diatas kemudian menimbulkan model pertanggungjawaban hukum yakni: ${ }^{13}$

1. Tanggung jawab dengan unsur kesalahan (kesengajaan dan kelalaian) sebagaimana dinyatakan dalam Pasal 1365 KUHPerdata;

2. Tanggung jawab dengan unsur kesalahan khususnya kelalaian sebagaimana dinyatakan dalam Pasal 1366 KUHPerdata; dan

3. Tanggung jawab mutlak (tanpa kesalahan) sebagaimana terdapat dalam Pasal 1367 KUHPerdata.

Pasal 1367 ayat (1) KUHPerdata mengatur bahwa seseorang tidak hanya bertanggung jawab, atas kerugian yang disebabkan perbuatannya sendiri, melainkan juga atas kerugian yang disebabkan perbuatan-perbuatan orang-orang yang menjadi tanggungannya atau disebabkan barang-barang yang berada di bawah pengawasannya. Pasal 1367 ayat (3) KUHPerdata kemudian menegaskan bahwa majikan dan orang yang mengangkat orang lain untuk mewakili urusan-urusan mereka, bertanggung jawab atas kerugian yang disebabkan oleh pelayan atau bawahan mereka dalam melakukan pekerjaan yang ditugaskan kepada orang- orang itu.

Terdapat pengecualian atau batasan terhadap pertanggungjawaban tersebut terhadap orang-orang yang secara tegas disebutkan dalam KUHPerdata, hal ini dapat

\footnotetext{
${ }^{11}$ R. Ali Rido, Badan Hukum dan Kedudukan Badan Hukum Perseroan, Perkumpulan, Koperasi, Yayasan, Wakaf, Bandung: PT Alumni, 2012, hlm. 1.

${ }^{12}$ Munir Fuady, Perbuatan Melawan Hukum, Cetakan 1, Bandung: Citra Aditya Bakti, 2002, hlm. 3 .

${ }^{13}$ Ibid.
}

44 Hermeneutika: Jurnal Ilmu Hukum Vol. 4, No. 1, Februari 2020 
kita lihat dalam pasal 1367 ayat (5) yang berbunyi: "Tanggung jawab yang disebutkan di atas berakhir jika orang tua-orang tua, wali-wali, guru-guru sekolah dan kepalakepala tukang itu membuktikan bahwa mereka tidak dapat mencegah perbuatan untuk mana mereka seharusnya bertanggung jawab itu."

Pasal 1367 ayat (3) KUHPerdata yang telah disebutkan di atas tidak terbatas pada tanggung jawab dalam ikatan kerja tetapi juga di luar ikatan kerja di mana pekerjaan tersebut dikerjakan secara mandiri baik atas pimpinan dari pemberi kerja ataupun hanya atas petunjuknya sesuai dengan ketentuan Pasal 1601 huruf (a) KUHPerdata tentang persetujuan perburuhan. Lingkup pertanggungjawaban Pasal 1367 ayat (3) KUHPerdata meliputi kerugian yang disebabkan oleh perbuatan yang tidak termasuk tugas yang diberikan pada bawahan namun ada hubungannya dengan tugas bawahan tersebut sehingga perbuatan tersebut dianggap dilakukan dalam hubungan dimana bawahan tersebut digunakan. Hoge Raad lebih lanjutnya menganut teori organ yang menjelaskan bahwa badan hukum dapat dimintai pertanggungjawaban secara perdata berdasarkan Pasal 1365 KUHPerdata apabila organnya melakukan perbuatan melawan hukum. ${ }^{14}$

Dalam konteks badan hukum tidak semua perbuatan dari organ dapat dipertanggungjawabkan kepada badan hukum tapi harus ada hubungan yang mendasari. Seseorang yang merupakan organ dari suatu badan hukum bertindak untuk memenuhi tugas yang diberikan kepadanya dan selanjutnya tindakan tersebut ternyata melawan hukum maka perbuatan seseorang yang merupakan organ tersebut dianggap sebagai perbuatan dari badan hukum dan badan hukum harus bertanggung jawab, sehingga secara langsung pertanggungjawaban perdata dari badan hukum dapat didasarkan pada Pasal 1365
KUHPerdata dan secara tidak langsung (apabila dilakukan oleh seseorang sebagai organ dari suatu badan hukum tersebut atau bawahan) didasarkan pada Pasal 1367 KUHPerdata.

\section{b. Perjanjian Kerja Sama (PKS) antara Koperasi Usaha Bersama "Mawar" dengan Bank BRI yang Memuat Pertanggungjawaban Pengurus Koperasi apabila Terjadi Kredit Macet dari Anggotanya}

Salah satu Koperasi yang bekerja sama dengan Bank BRI dalam Linkage Program Pola Channeling adalah Koperasi Usaha Bersama "Mawar". Pertanggungjawaban pengurus Koperasi yang bekerja sama dengan Bank BRI atas adanya kredit macet dalam Linkage Program Pola Channeling diselesaikan melalui Perjanjian Kerja Sama (PKS) yang telah disepakati oleh kedua belah pihak untuk bekerja sama dalam penyaluran fasilitas kredit melalui Linkage Program. Bank BRI dalam melakukan perjanjian penyaluran kredit dengan lembaga perserta Linkage Program Pola Channeling seperti Koperasi membebankan pertanggungjawaban kepada anggota Koperasi sebagai debitur. Kendati demikian, dalam PKS yang disepakati oleh Koperasi Usaha Bersama "Mawar" dengan Bank BRI, terdapat klausul di mana Koperasi bersedia untuk menjadi avalis atau penjamin bayar.

Anggota Koperasi sebagai debitur dalam hal Pola Channeling yang harus bertanggung jawab terhadap dana yang dipinjamkan, bukan lembaga pembiayaan seperti Koperasi. Apabila anggota Koperasi tidak dapat segera bertanggung jawab atas kredit macet, maka sesuai PKS yang disepakati keduanya, Koperasi Usaha Bersama "Mawar" sebagai pihak yang merekomendasikan Anggotanya untuk mendapatkan fasilitas kredit dari Bank BRI, tetap dapat dimintakan pertanggungjawaban

\footnotetext{
${ }^{14}$ Moegni Djojodirdjo, Perbuatan Melawan Hukum, Jakarta: Pradnya Paramita, 1982, hlm. 128-176.
} 
oleh Bank BRI melalui PKS yang telah disepakati keduanya.

Dalam konteks badan hukum tidak semua perbuatan dari organ dapat dipertanggungjawabkan kepada badan hukum tapi harus ada hubungan yang mendasari. Hubungan yang mendasari tersebut dalam hal pertanggungjawaban pengurus Koperasi dapat didasari atas dua hal yaitu:

a. berdasarkan pada Anggaran Dasar (AD) dan Anggaran Rumah Tangga (ART) mereka; dan

b. berdasarkan Perjanjian Kerja Sama yang disepakati oleh Koperasi dengan Bank untuk perjanjian kerja sama dalam Linkage Program Pola Channeling.

Anggaran Dasar (AD) Koperasi yang termuat dalam Akta Pendirian Koperasi sebagaimana yang telah diatur dalam Pasal 8 UU Perkoperasian memuat ketentuan mengenai sanksi, di mana hal tersebut memuat hak dan kewajiban Anggota, Pengawas, dan Pengurus. Pasal 11 ayat (3) Peraturan Menteri Koperasi dan Usaha Kecil Menengah No. 10/Per/M.KUKM/IX/2015 tentang Kelembagaan Koperasi telah menyebutkan bahwa setelah Akta Pendirian Koperasi disahkan, Rapat Anggota memutuskan untuk menerima atau menolak tanggung jawab pengurus atas kegiatan usaha atau tindakan hukum sebagai tanggung jawab Koperasi. Apabila Rapat Anggota menerima, maka kegiatan usaha atau tindakan hukum yang telah dilaksanakan pengurus menjadi tanggung jawab Koperasi. Apabila Rapat Anggota menolak maka segala akibat yang timbul dari kegiatan usaha atau tindakan hukum yang telah dilaksanakan pengurus menjadi tanggung jawab pengurus baik secara sendiri-sendiri maupun bersama-sama.

Dalam hal yang mendasari pembebanan pertanggungjawaban pengurus Koperasi, selain Anggaran Dasar (AD), terdapat pula Perjanjian Kerja Sama. Perjanjian Kerja Sama (PKS) yang disepakati oleh Koperasi Usaha Bersama "Mawar" dengan Bank BRI dalam perjanjian kerja sama Linkage Program Pola
Channeling, memuat klausul yang menjelaskan mengenai bentuk pertanggungjawaban di antara keduanya. Perjanjian Kerja Sama (PKS) yang dilakukan Bank BRI dengan Koperasi Usaha Bersama "Mawar" sebagai peserta Linkage Program Pola Channeling memuat klausul bahwa Koperasi menjadi avalis atau penjamin bayar dari anggotanya, sehingga jika terjadi kredit macet maka Koperasi harus menyelesaikan kewajiban anggotanya.

Koperasi dalam menyelesaikan kewajiban anggotanya tersebut sejalan dengan tanggung jawab pengurus Koperasi secara konsep teoritis, yaitu tidak terbatas. Berbeda dengan tanggung jawab persero dalam Perseroan Terbatas, dimana hanya terbatas pada saham yang dimilikinya. Tanggung jawab pengurus Koperasi diatur dalam Pasal 34 Undang-Undang Nomor 25 Tahun 1992 tentang Perkoperasian yang dengan jelas menerangkan bahwa tanggung jawab yang harus dipikul oleh setiap pengurus operasi adalah secara bersamasama atau secara tanggung renteng, walaupun dalam keadaan tertentu tanggung jawabnya adalah secara individual.

$$
\text { Perjanjian Kerja Sama (PKS) }
$$

Linkage Program Pola Channeling yang dilakukan Koperasi dapat menjadi dasar dibebankannya pertanggungjawaban. Apabila tidak ada Perjanjian Kerja Sama yang dilakukan oleh Koperasi dengan Bank, maka menjadi tidak ada masalah bagi pengurus Koperasi dikarenakan yang mempunyai kewajiban untuk bertanggung jawab ialah yang berwenang memutuskan, bukan yang hanya memfasilitasi seperti Koperasi pada pola channeling.

Koperasi Usaha Bersama "Mawar" dalam hal ini berarti harus menyelesaikan kewajiban anggotanya kepada Bank BRI. Sehingga, walaupun pada konsepnya pertanggungjawaban kredit macet dibebankan kepada debitur dan Koperasi hanya bertanggung jawab secara administrasi atau dokumentasi berkas pinjaman, namun dalam hal terjadi kredit macet maka tetap dimungkinkan pengurus Koperasi Usaha Bersama "Mawar" untuk 
membayar tagihan pembayaran kredit anggotanya yang macet atas dasar PKS tersebut.

Pertanggungjawaban Koperasi Usaha Bersama "Mawar" untuk menyelesaikan kewajiban anggotanya apabila terjadi kredit macet dapat dilakukan dengan diholdnya giro operasional Koperasi. Koperasi wajib menyetorkan apabila giro operasional tersebut kurang dari jumlah minimum.

Pengurus Koperasi Usaha Bersama "Mawar" dapat dibebankan pertanggungjawaban atas kewajiban anggotanya yang tidak dipenuhi kepada Bank BRI, apabila pengurus Koperasi tersebut memenuhi unsur Pasal 1365 KUHPerdata. Pengurus Koperasi Usaha Bersama "Mawar" namun tidak dapat dibebankan pertanggungjawaban atas pribadi apabila ia bertindak untuk memenuhi tugas yang diberikan kepadanya dan selanjutnya tindakan tersebut ternyata melawan hukum, maka perbuatan seseorang yang merupakan organ tersebut dianggap sebagai perbuatan dari badan hukum dan badan hukum harus bertanggung jawab.

Pertanggungjawaban Koperasi Usaha Bersama "Mawar" sebagai badan hukum maka dengan kondisi di mana pengurusnya bertindak untuk memenuhi tugas yang diberikan kepadanya dan selanjutnya tindakan tersebut ternyata melawan hukum, maka tidak akan dibebankan kepada harta kekayaan pribadi pengurus.

Koperasi Usaha Bersama "Mawar" sebagai lembaga yang bekerja sama dengan Bank BRI, akan melakukan pertanggungjawaban dengan cara menjadi avalis atau penjamin bayar atas anggotanya, seperti yang tertera dalam Perjanjian Kerja Sama (PKS) yang dilakukan keduanya, padahal secara konseptual dalam Linkage Program Pola Channeling, pertanggungjawaban Koperasi hanya sebatas pada administrasi atau dokumentasi berkas pinjaman dikarenakan Koperasi dalam pola channeling hanya berperan sebagai lembaga perantara atau agen yang memfasilitasi hubungan antara Bank yang mencari calon nasabah dengan anggota Koperasi yang merupakan calon nasabah untuk diberikan fasilitas pinjaman kredit melalui linkage program pola channeling, dalam hal ini Koperasi tidak mempunyai wewenang untuk memutus kredit sehingga pencatatan di Bankpun yang menjadi peminjam adalah anggota Koperasi, bukan Koperasi.

\section{KESIMPULAN}

Pertanggungjawaban pengurus Koperasi apabila terjadi kredit macet dari anggota Koperasi dalam Linkage Program Pola Channeling dapat didasari dari dua hal, yaitu: berdasarkan Anggaran Dasar (AD) dan Anggaran Rumah Tangga (ART) mereka; dan/atau berdasarkan Perjanjian Kerja Sama. Apabila tidak ada Perjanjian Kerja Sama yang dilakukan oleh Koperasi dengan Bank, maka menjadi tidak ada masalah bagi pengurus Koperasi dikarenakan yang mempunyai kewajiban untuk bertanggung jawab ialah yang berwenang memutuskan, bukan yang hanya memfasilitasi seperti Koperasi pada pola channeling. Namun, pada Perjanjian Kerja Sama yang disepakati oleh Bank BRI dengan Koperasi Usaha Bersama "Mawar" dalam Linkage Program Pola Channeling, terdapat klausul di mana Koperasi memiliki kewajiban untuk menyelesaikan kewajiban anggotanya, padahal Koperasi dalam pola channeling hanya sebagai lembaga yang memfasilitasi, bukan yang memutuskan untuk memberikan kredit.

Mengingat bahwa Koperasi dalam pola channeling hanya menjadi lembaga perantara yang menfasilitasi, dan bukan lembaga yang memutuskan pemberian kredit, maka dalam hal pembuatan Perjanjian Kerja Sama dengan Bank kiranya Koperasi haruslah lebih melihat klausul-klausul yang diperjanjikan di dalamnya, seperti untuk menyelesaikan kewajiban anggotanya apabila anggotanya tidak mampu menyelesaikan. Koperasi sebagai lembaga perantara dalam linkage program pola channeling seharusnya lebih berhati-hati dalam menseleksi anggotanya yang ingin mengajukan pinjaman kredit dengan Bank 
melalui Koperasi dengan linkage program pola channeling.

\section{DAFTAR PUSTAKA}

Ali, Chidir. (1999). Badan Hukum. Bandung: Penerbit Alumni.

Djojodirdjo, Moegni. (1982). Perbuatan Melawan Hukum. Jakarta: Pradnya Paramita.

Fathoni, "Masyarakat Ekonomi Asean (MEA) 2015 dan Tantangan Negara Kesejahteraan", Jurnal Penelitian Hukum Supremasi Hukum, Volume 24, Nomor 2, 2015.

Fuady, Munir. (2002). Perbuatan Melawan Hukum, Cetakan 1. Bandung: Citra Aditya Bakti.

H.A.M. Nurdin Halid, (1999). Membangun Simbol, Meruntuhkan Mitos Marginal Koperasi. Jakarta: Forum Studi dan Solidaritas Koperasi Indonesia.
Muhammad, Abdulkadir. (2010). Hukum Perusahaan Indonesia. Bandung: PT Citra Aditya Bakti.

Partomo, T.S. (2009). Ekonomi Koperasi, Bogor: Ghalia Indonesia.

Prodjodikoro, Wirjono. (1985). Hukum Perkumpulan Perseroan Dan Koperasi di Indonesia. Bandung: Penerbit Dian Rakyat.

Rido, R.A. (2012). Badan Hukum dan Kedudukan Badan Hukum Perseroan, Perkumpulan, Koperasi, Yayasan, Wakaf. Bandung: PT Alumni.

Sugiyono. (2009). Metode Penelitian Bisnis (Pendekatan Kuantitatif, Kualitatif, dan $R \& D)$. Bandung: Alfabeta.

Zuldi Diane Zaini. (2011). Implementasi Pendekatan Yuridis Normatif dan Pendekatan Normatif Sosiologis dalam Penelitian Ilmu Hukum. Pranata Hukum Volume 6 Nomor 2. 